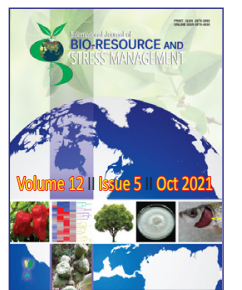

\title{
Micronutrient Fortification of Pearl Millet [Pennisetum glaucum (L.) R. Br.] Hybrids using Customized Fertilizer Formulation
}

\author{
Manoj Kumar ${ }^{1}$, Ummed Singh² ${ }^{*}$, P. R. Raiger ${ }^{2}$, L. Netajit Singh ${ }^{2}$, H. P. Parewa ${ }^{3}$ and Rekha Chouhan ${ }^{4}$ \\ ${ }^{1}$ ICAR-All India Coordinated Research Project on Pearl millet, Agriculture University, Jodhpur, Rajasthan (342 304), India \\ ${ }^{2}$ College of Agriculture, Agriculture University, Jodhpur, Rajasthan (342 304), India \\ ${ }^{3}$ College of Agriculture, Sumerpur, Pali, Rajasthan (306 902), India \\ ${ }^{4}$ Rajasthan State Seeds Corporation Limited, Jodhpur, Rajasthan (342 304), India
}

Open Access

Corresponding Author

Ummed Singh

e-mail: singhummed@yahoo.co.in

Citation: Kumar et al., 2021. Micronutrient Fortification of Pearl Millet [Pennisetum glaucum (L.) R. Br.] Hybrids using Customized Fertilizer Formulation. International Journal of Bio-resource and Stress Management 2021, 12(5), 416-425. HTTPS://DOI ORG/10.23910/1.2021.2438.

Copyright: (c) 2021 Kumar et al. This is an open access article that permits unrestricted use, distribution and reproduction in any medium after the author(s) and source are credited.

Data Availability Statement: Legal restrictions are imposed on the public sharing of raw data. However, authors have full right to transfer or share the data in raw form upon request subject to either meeting the conditions of the original consents and the original research study. Further, access of data needs to meet whether the user complies with the ethical and legal obligations as data controllers to allow for secondary use of the data outside of the original study.

Conflict of interests: The authors have declared that no conflict of interest exists.

Acknowledgement: The authors duly acknowledge the support received from the ICAR-All India Coordinated Research Project on Pearl Millet, Agricultural Research Station, Mandor, Jodhpur (Agriculture University, Jodhpur). Our sincere thanks are also due to the College of Agriculture, Agriculture University, Jodhpur for providing facilities for accomplishing the research work.

\begin{abstract}
The studies were undertaken at ICAR-AICRP on Pearl Millet, Research Farm, ARS, Mandor, Jodhpur (Agriculture University, Jodhpur), Rajasthan, India during July to October of both the 2019 and 2020. The experiment was consisted of three fertilizers (Control, Nutrient supply through straight fertilizers and Nutrient supply through customized fertilizer) and seven pearl millet hybrids ('MPMH 21', 'MPMH 17', 'RHB 177', 'RHB 173', 'HHB 67 (Improved)', 'HHB 197' and 'HHB 272') in FRBD and replicated thrice. Findings revealed, application of customized fertilizer of the grade $6: 6: 2: 1\left(\mathrm{~N}: \mathrm{P}_{2} \mathrm{O}_{5}: \mathrm{K}_{2} \mathrm{O}: \mathrm{Zn}\right)$ to pearl millet substantially enhanced $\mathrm{Zn}$ concentration in the roots, shoots, and leaves at panicle initiation $(47.30,54.31$, $\left.52.33 \mathrm{mg} \mathrm{kg}^{-1}\right), 50 \%$ flowering $\left(40.30,50.96,50.10 \mathrm{mg} \mathrm{kg}^{-1}\right.$ ) and at harvest (45.27, $\left.46.54,47.29 \mathrm{mg} \mathrm{kg}^{-1}\right)$, respectively, over control. Similarly, Fe concentration in the roots, shoots and leaves were also increased markedly due to the application of customized fertilizer. Substantially higher Zn (56.42 $\left.\mathrm{mg} \mathrm{kg}^{-1}\right)$, Fe $\left(39.50 \mathrm{mg} \mathrm{kg}^{-1}\right)$, $\mathrm{Mn}\left(15.13 \mathrm{mg} \mathrm{kg}^{-1}\right)$ and $\mathrm{Cu}\left(18.31 \mathrm{mg} \mathrm{kg}^{-1}\right)$ concentrations in the pearl millet grain was also fetched by applying customized fertilizer. Moreover, customized fertilizer application statistically enhanced grain $(2,010 \mathrm{~kg})$ and straw $(3,417 \mathrm{~kg})$ yields over control. Among pearl millet hybrids, 'HHB 67 Improved' recorded substantially higher Zn (61.97 $\left.\mathrm{mg} \mathrm{kg}^{-1}\right)$, Fe (43.98 $\left.\mathrm{mg} \mathrm{kg}^{-1}\right)$ and $\mathrm{Mn}(15.46 \mathrm{mg} \mathrm{kg}$ $\left.{ }^{1}\right)$ concentration in grain and $\mathrm{Cu}\left(25.09 \mathrm{mg} \mathrm{kg}^{-1}\right)$ concentration in straw. Albeit, 'HHB 173' noticed significantly higher $\mathrm{Cu}\left(19.60 \mathrm{mg} \mathrm{kg}^{-1}\right)$ concentration in grain. Further, among hybrids, 'MPMH 17' out yielded $\left(1,958 \mathrm{~kg} \mathrm{ha}^{-1}\right)$ followed by 'RHB $173^{\prime}\left(1,795 \mathrm{~kg} \mathrm{ha}^{-1}\right)$.
\end{abstract}

Keywords: Biofortification, customized fertilizer, micronutrients, pearl millet, zinc

\section{Introduction}

Micronutrient malnutrition or 'Hidden Hunger' is known to affect more than half of the world's population and is considered to be among the most serious global challenges to humankind (Singh et al., 2016). The distressingly increasing population growth would likely lead towards a remarkably enhanced proportion of people that suffer from nutrient scarcity, more particularly the micronutrient deficiencies. The minerals that are indispensable to human health include a wide range of macro [sodium ( $\mathrm{Na})$, potassium (K), calcium (Ca), magnesium (Mg), sulfur (S),

Article History

RECEIVED on $18^{\text {th }}$ June 2021 RECEIVED in revised form on $15^{\text {th }}$ September 2021 ACCEPTED in final form on 03 ${ }^{\text {rd }}$ October 2021 
phosphorus $(\mathrm{P})$ and chlorine $(\mathrm{Cl})$ ] and micro-nutrients or trace elements [iron (Fe), zinc ( $\mathrm{Zn})$, copper (Cu), manganese (Mn), iodine (I), fluorine (F), selenium (Se), molybdenum (Mo), cobalt (Co) and boron (B)] (Bouis and Welch, 2010). Currently, more than half of the world population encounters the critical problem of micronutrient malnutrition. Among micronutrients, zinc is an important nutrient for the growth and development of plants which requires a proper balance of all the essential nutrients for normal growth and optimum yield. It is required as a structural component of a large number of proteins, such as transcription factors and metallo enzymes and plays a very important role in plant metabolism by influencing the activities of hydrogenase and carbonic anhydrase, stabilization of ribosomal fractions and synthesis of cytochrome (Dev and Singh, 2020). Plant enzymes activated by $\mathrm{Zn}$ are involved in carbohydrate metabolism, maintenance of the integrity of cellular membranes, protein synthesis, and regulation of auxin synthesis and pollen formation (Marschner, 1995; Hafeez et al., 2013; Shahzad et al., 2014; Singh et al., 2015). The regulation and maintenance of the gene expression required for the tolerance of environmental stresses in plants are $\mathrm{Zn}$ dependent (Cakmak and Kutman, 2017). Its deficiency results in the development of abnormalities in plants which become visible as deficiency symptoms such as stunted growth, chlorosis and smaller leaves, spikelet sterility. Zn deficiency can also adversely affect the quality of harvested products; plants susceptible to injury by high light or temperature intensity (Marschner, 1995; Cakmak and Kutman, 2017). Likewise, iron is also acentral component of electron chains and a co-factor of several vital enzymes. In plants, iron is also required for photosynthesis and chlorophyll synthesis. The availability of iron in soils dictates the distribution of plant species in natural ecosystems and limits yield and nutritional quality of crops (Morrissey and Guerinot, 2009). Roots of plant species take up $\mathrm{Zn}, \mathrm{Fe}, \mathrm{Mn}$ and $\mathrm{Cu}$ in their cationic forms. Of the 17 essential plant nutroents, $\mathrm{Mn}$ in plants is required for growth and reproduction. Although its requirement is trace by plants, but is ultimately as critical to growth as are the other nutrients. Manganese is essential element of the metalloenzyme cluster of the oxygen-evolving complex (OEC) in photosystem II (PSII) in photosynthetic plants (Alejandro et al., 2020). Copper is also a large number of enzymes related to respiration and photosynthesis (Marschner, 1995) and acts as structural element in regulatory proteins and participates in photosynthetic electron transport, oxidative stress responses and hormone signalling.

Farmers have applied mineral fertilizers to the soil for hundreds of years in order to improve plants health, albeit within certain limits similar strategy can also be advocated to enhance mineral accumulation within cereal grains for nutritional purposes (Rengel et al., 1999). Such a strategy of agronomic biofortification only works if the mineral deficiency in the grain reflects the absence of that mineral in the soil and if the mineral fertilizer contains minerals that are rapidly and easily mobilizable. Also, even if plants can absorb minerals efficiently from the soil, and may store the mineral in leaves but fails to translocate it to the fruits or seeds, or they may accumulate the mineral in a form that is not bioavailable, consequently having no substantial impact on nutrition (Frossard et al., 2000). Like supplements and fortification, agronomic intervention is probably best applied in niche situations or combination with other strategies (Cakmak, 2008). Agronomic strategies to increase the concentrations of mineral elements in edible tissues generally rely on the application of mineral fertilizers and/or improvement of the solubilization and mobilization of mineral elements in the soil (White and Broadley, 2009; Singh et al., 2015a). When crops are grown where mineral elements become immediately unavailable in the soil, targeted application of soluble inorganic fertilizers to roots or leaves is practiced. Therefore, customized fertilizer having a slow matrix to release the plant nutrient to the plants and capable to enhance nutrient concentration in the economic plant part i.e. grain (Singh et al., 2016a; Singh et al., 2020). As identified, customized fertilizer is a multi-nutrient carrier designed to contain macro and/or micronutrient forms, both from inorganic and/or organic sources, manufactured through a systematic process of granulation, satisfying the crop's nutritional needs, specific to its site, soil and stage, validated by a scientific crop model capability developed by an accredited fertiliser manufacturing/marketing company is a mixed fertilizer formulated according to individual specifications furnished by the consumers before mixing. The customized fertilizers are a combination of micro and macro plant nutrients and are made up through a process of granulation under strictly controlled conditions (Singh et al., 2017). These fertilizers are capable to increase nutrient use efficiency, grain nutritional quality and are helpful in soil fertility status improvement.

In India, pearl millet is the fourth most widely cultivated food crop after rice, wheat and maize. Currently, pearl millet covers an acreage of 7.54 million hectares with a production of 10.36 million tonnes and $1374 \mathrm{~kg} \mathrm{ha}^{-1}$ productivity (Anonymous, 2020). Presently, Farmers' in drier parts of the country are not well acquainted with hybrids and fertilizer sources for grain enrichment. To answer the questions of efficient fertilizer source and high yielding pearl millet hybrid and is nutritionally responsive, the present investigation was undertaken.

\section{Materials and Methods}

\subsection{Description of the study area}

The field experiments were conducted at ICAR-All India Coordinated Research Project on Pearl Millet, Research Farm, Agricultural Research Station, Mandor, Jodhpur (Agriculture University, Jodhpur), Rajasthan, India during July to October months of 2019 and 2020 . The geographically experimental site was located between $26^{\circ} 15^{\prime} \mathrm{N}$ to $26^{\circ} 45^{\prime}$ North latitude and $73^{\circ} 00^{\prime} \mathrm{E}$ to $73^{\circ} 29^{\prime}$ East longitude at an altitude of 231 
meters above mean sea level. This region falls under agroclimatic zone la (Arid Western Plain Zone) of Rajasthan.

During the cropping period of pearl millet, the mean weekly maximum and minimum temperature fluctuated between $25.6^{\circ} \mathrm{C}$ to $35.2^{\circ} \mathrm{C}$ during 2019 and $28.1^{\circ} \mathrm{C}$ to $35.4^{\circ} \mathrm{C}$ during 2020. The experimental crop received 537.7 and $223.3 \mathrm{~mm}$ of rainfall with 24 and 15 rainy days during 2019 and 2020, respectively. The average weekly relative humidity fluctuated between 48.5 to $76.1 \%$ and 46.2 to $71.0 \%$ during 2019 and 2020 , respectively. The soil of the experimental field was sandy loam in texture, well drained with a low level of organic carbon, available nitrogen and diethylene tri-amine penta acetic acid (DTPA) extractable zinc. However, it was medium in available phosphorus and high in available potassium. The experimental soil was non-saline with slightly alkaline in reaction. The details of the physico-chemical properties of the experimental soil for both years are presented in Table 1.

Table 1: Physico-chemical characteristics of the experimental field $(0-15 \mathrm{~cm})$

\begin{tabular}{lcc}
\hline Soil parameters & \multicolumn{2}{c}{ Value } \\
\hline & 2019 & 2020 \\
$\mathrm{pH}$ & 8.20 & 8.20 \\
$\left.\mathrm{EC}(\mathrm{dS} \mathrm{m})^{-1}\right)$ & 0.13 & 0.12 \\
Organic carbon $\left(\mathrm{g} \mathrm{kg}^{-1}\right)$ & 1.13 & 1.13 \\
Bulk density $\left(\mathrm{Mg} \mathrm{m}^{-3}\right)$ & 1.54 & 1.55 \\
Available N $\left(\mathrm{kg} \mathrm{ha}^{-1}\right)$ & 158.2 & 159.3 \\
Available P2O5 $\left(\mathrm{kg} \mathrm{ha}^{-1}\right)$ & 15.8 & 16.0 \\
Available K2O $\left(\mathrm{kg} \mathrm{ha}^{-1}\right)$ & 284.7 & 283.4 \\
DTPA extractable $\mathrm{Zn}\left(\mathrm{mg} \mathrm{kg}^{-1}\right)$ & 0.43 & 0.44 \\
DTPA extractable Fe $\left(\mathrm{mg} \mathrm{kg}^{-1}\right)$ & 3.91 & 3.13 \\
DTPA extractable Mn $\left(\mathrm{mg} \mathrm{kg}^{-1}\right)$ & 7.62 & 7.48 \\
DTPA extractable Cu $\left(\mathrm{mg} \mathrm{kg}^{-1}\right)$ & 0.46 & 0.51 \\
Soil texture & Sandy loam & Sandy loam \\
\hline
\end{tabular}

2.2. Experimental design and procedure

The field experiments were laid out in Factorial Randomized Block Design (FRBD) and replicated thrice. The treatments were randomly allotted to different plots, using the random number table of Fisher and Yates (1963). The experiment consisted of three fertility levels (Control, Nutrient supply through straight fertilizers and Nutrient supply through customized fertilizer) and seven different pearl millet hybrids ('MPMH 21', 'MPMH 17', 'RHB 177', 'RHB 173', 'HHB 67 (Improved)', 'HHB 197' and 'HHB 272'). In pearl millet, customized fertilizer of the grade 6:6:2:1 ( $\left.\mathrm{N}: \mathrm{P}_{2} \mathrm{O}_{5}: \mathrm{K}_{2} \mathrm{O}: \mathrm{Zn}\right)$ was prepared in the Agronomy Lab, College of Agriculture, Jodhpur and applied as per treatments in the form of basal dose at the time of sowing. The recommended dose of fertilizers to the experimental crop of pearl millet at $60 \mathrm{~kg} \mathrm{~N}, 30 \mathrm{~kg}$
$\mathrm{P}_{2} \mathrm{O}_{5}, 10 \mathrm{~kg} \mathrm{~K}_{2} \mathrm{O}$ and $5 \mathrm{~kg} \mathrm{Zn} \mathrm{ha-1}$ was applied through straight fertilizers viz; urea, diammonium phosphate (DAP), muriate of potash (MOP) and zinc oxide, respectively. Complete dose of phosphorus, potassium and zinc and half dose of nitrogen (30 kg) were applied to the crop as basal dose at the time of sowing. Whereas, the remaining $30 \mathrm{~kg}$ dose of $\mathrm{N}$ for both the treatments i.e. customized fertilizer and RDF through straight fertilizers was applied through neem coated urea in the form of top dressing at 30 DAS. Treatments were applied as per standard methods. The crop of pearl millet was sown on July 21, 2019 and July 7, 2020. Sowing of seeds was done in rows through kera/pora methods during both seasons. Pearl millet was sown at a row to row spacing of $45 \mathrm{~cm}$ and $15 \mathrm{~cm}$ plant to plant using $4 \mathrm{~kg}$ seeds ha-1.

The representative samples of pearl millet plant parts viz; root, shoot and leaf at panicle initiation, 50\% flowering and at harvest were collected carefully avoiding any external contamination. The collected samples were washed in the double distilled water, dried and grounded for analyzing zinc and iron content (Singh and Praharaj, 2017). At harvest, samples of grain and straw were drawn from each plot of the experiment for the chemical analysis of $\mathrm{Zn}, \mathrm{Fe}, \mathrm{Mn}$ and $\mathrm{Cu}$ concentration. Zinc and iron in root, shoot, leaves and zinc, iron, manganese and copper concentration in grain and straw samples were digested using di-acid $\left(\mathrm{HClO}_{4}+\mathrm{HNO}_{3}\right.$ in 4:9 ratio) mixture. Mineral concentrations ( $\mathrm{Zn}, \mathrm{Fe}, \mathrm{Mn}$ and $\mathrm{Cu}$ ) of the filtrates were measured using Atomic Absorption Spectrophotometer (Singh and Praharaj, 2017).

These experimental data recorded under observations were statistically analyzed in accordance with the 'Analysis of Variance' technique as described by Fisher (1950). Wherever variance ratio (F value) was found significant, critical difference (CD) values at $5 \%$ level of probability were computed for making a comparison between treatments. To elucidate the nature and magnitude of treatments effects, standard errors of means (SEm \pm ) and $C D(p=0.05)$ were computed. The data recorded on different parameters were pooled, as the differences between the years were not significant.

\section{Results and Discussion}

\subsection{Zinc partitioning in plant parts}

Application of customized fertilizer to pearl millet substantially enhanced zinc concentration in the root, shoot and leaf at varying growth stages viz; panicle initiation, $50 \%$ flowering and at harvest stage (Table 2). Application of customized fertilizer enhanced zinc concentration in the root by $6.22,5.99$ and 6.07 percent at panicle initiation, $50 \%$ flowering and at harvest stage, respectively, over control. Likewise, zinc concentration improvement in the shoot at varying growth stages viz; panicle initiation, $50 \%$ flowering and at harvest stage was to the extent of 5.33, 6.12 and $5.70 \%$ higher, respectively, over control or no fertilizer application. Similarly, the enhancement in terms of zinc concentration the leaves of pearl millet was also recorded higher by $5.16,4.96$ and $5.53 \%$ at panicle 


\begin{tabular}{|c|c|c|c|c|c|c|c|c|c|}
\hline \multirow[t]{3}{*}{ Treatments } & \multicolumn{9}{|c|}{ Zinc concentration $\left(\mathrm{mg} \mathrm{kg}^{-1}\right)$} \\
\hline & \multicolumn{3}{|c|}{ Panicle initiation } & \multicolumn{3}{|c|}{$50 \%$ flowering } & \multicolumn{3}{|c|}{ At harvest } \\
\hline & Root & Shoot & Leaf & Root & Shoot & Leaf & Root & Shoot & Leaf \\
\hline \multicolumn{10}{|l|}{ Fertilizers } \\
\hline Control & 44.53 & 51.56 & 49.76 & 38.02 & 48.02 & 47.73 & 42.68 & 44.03 & 44.81 \\
\hline Straight fertilizer & 44.98 & 53.51 & 51.60 & 38.66 & 50.12 & 49.50 & 44.70 & 45.81 & 46.69 \\
\hline Customized fertilizer & 47.30 & 54.31 & 52.33 & 40.30 & 50.96 & 50.10 & 45.27 & 46.54 & 47.29 \\
\hline SEm \pm & 0.05 & 0.05 & 0.04 & 0.07 & 0.06 & 0.06 & 0.06 & 0.05 & 0.09 \\
\hline $\mathrm{CD}(p=0.05)$ & 0.14 & 0.13 & 0.12 & 0.20 & 0.17 & 0.18 & 0.16 & 0.15 & 0.25 \\
\hline \multicolumn{10}{|l|}{ Hybrids } \\
\hline$\overline{\text { MPMH } 21}$ & 45.81 & 52.24 & 51.51 & 38.22 & 50.70 & 48.02 & 44.53 & 43.46 & 43.10 \\
\hline MPMH 17 & 41.41 & 54.13 & 49.45 & 33.24 & 50.63 & 44.09 & 42.24 & 46.26 & 41.64 \\
\hline RHB 177 & 46.12 & 54.19 & 49.45 & 40.87 & 51.44 & 49.49 & 43.00 & 47.42 & 47.91 \\
\hline RHB 173 & 42.22 & 53.79 & 50.15 & 37.57 & 48.58 & 48.51 & 45.85 & 46.10 & 45.71 \\
\hline HHB 67 Improved & 46.97 & 53.17 & 51.47 & 37.34 & 50.32 & 52.08 & 43.64 & 46.07 & 50.42 \\
\hline HНB 197 & 48.54 & 52.17 & 53.13 & 41.20 & 47.68 & 52.28 & 42.13 & 43.32 & 49.36 \\
\hline HHB 272 & 48.17 & 52.20 & 53.43 & 44.51 & 48.54 & 49.28 & 48.14 & 45.59 & 45.71 \\
\hline SEm \pm & 0.08 & 0.07 & 0.07 & 0.11 & 0.09 & 0.10 & 0.09 & 0.08 & 0.13 \\
\hline $\mathrm{CD}(p=0.05)$ & 0.22 & 0.20 & 0.19 & 0.30 & 0.26 & 0.27 & 0.25 & 0.22 & 0.37 \\
\hline \multicolumn{10}{|l|}{ Interaction } \\
\hline SEm \pm & 0.13 & 0.12 & 0.12 & 0.18 & 0.16 & 0.17 & 0.15 & 0.14 & 0.23 \\
\hline$C D(p=0.05)$ & 0.37 & 0.34 & NS & 0.52 & NS & NS & NS & NS & NS \\
\hline
\end{tabular}

initiation, 50\% flowering and at harvest stage, respectively, over control. The major reason for higher concentration $\mathrm{Zn}$ due to application of customized fertilizer which contains $\mathrm{N}$, $\mathrm{P}$ and $\mathrm{K}$ along with micronutrients in formulation enhanced the efficiency of micronutrient as compared over straight application of nutrient (Beuerlein et al., 1992). Therefore, an appropriate combination of NPK and Zn nutrients provided through formulation might enhance the $\mathrm{Zn}$ concentration at all the growth stages of pearl millet. The concentration of $\mathrm{Zn}$ is also ascribed to an improved nutritional environment in soil rhizosphere, slow release matrix and consequently higher absorption in plant system by varying plant parts (Singh et al., 2017). Further, the order of zinc concentration in pearl millet plant parts at varying phonological events was in the order: shoot $\left(54.31 \mathrm{mg} \mathrm{kg}^{-1}\right)>$ leaf $\left(52.33 \mathrm{mg} \mathrm{kg}^{-1}\right)>$ root $(47.30 \mathrm{mg} \mathrm{kg}$ $\left.{ }^{1}\right)$ at panicle initiation; shoot $\left(50.96 \mathrm{mg} \mathrm{kg}^{-1}\right)>1$ eaf $(50.10 \mathrm{mg}$ $\left.\mathrm{kg}^{-1}\right)>\operatorname{root}\left(40.30 \mathrm{mg} \mathrm{kg}^{-1}\right)$ at $50 \%$ flowering and leaf $(47.29 \mathrm{mg}$ $\left.\mathrm{kg}^{-1}\right)>$ shoot $\left(46.54 \mathrm{mg} \mathrm{kg}^{-1}\right)>$ root $\left(45.27 \mathrm{mg} \mathrm{kg}^{-1}\right)$. The reason for the higher concentration in leaves at harvest may be due to the fact that at adequate nutrient supply, the leaves of the pearl millet were a major reserve of zinc at maturity. These observations are consistent with the results of Jakhar et al. (2006); Singh et al. (2015) and Karmakar et al. (2021)

Marked variations in terms of zinc concentration in different plant parts of pearl millet were recorded due to various hybrids tested under the study (Table 2). The trend of zinc concentration increment was different for different plant parts among the pearl millet hybrids. Pearl millet hybrid 'RHB 177' recorded substantially higher zinc concentration in shoots at panicle initiation (54.19 $\left.\mathrm{mg} \mathrm{kg}^{-1}\right)$, at $50 \%$ flowering (51.44 $\mathrm{mg} \mathrm{kg}{ }^{-1}$ ) and harvest $\left(47.42 \mathrm{mg} \mathrm{kg}^{-1}\right)$. However, pearl millet hybrid 'HHB 197' fetched markedly higher zinc concentration in root at panicle initiation $\left(48.54 \mathrm{mg} \mathrm{kg}^{-1}\right)$ and in leaves at $50 \%$ flowering $\left(52.28 \mathrm{mg} \mathrm{kg}^{-1}\right)$. Increased supply of zinc favoured increased zinc accumulation in the entire plant. The increase in zinc concentration showed adequate zinc supply treatments may also be due to increased availability of zinc to the crop through xylem transport from root to shoot in the transpiration stream. The results are supported by the findings of Samreen et al. (2017). These results also corroborate the findings of Fageria (2013). Graham and Rengel (1993) suggested that more than one mechanism could be responsible for establishing zinc efficiency in a genotype and are likely that different genotypes subjected to zinc deficiency under different climatic conditions will respond by, one or more, different crop management practices. Hafeez et al. (2013) reported that efficient genotypes are those with a high capacity to absorb the nutrients from the root zone and store 
relatively little nutrients. The mechanisms responsible for this tolerance of genotypes in low zinc availability conditions include multifarious reasons and one of the major causes being the increased zinc bioavailability in the root zone due to release of root exudates, higher uptake of zinc by roots, and efficient utilization and re-translocation of zinc (Sadeghzadeh, 2013).

\subsection{Iron partitioning in plant parts}

Application of customized fertilizer to pearl millet markedly influenced iron concentration in different plant parts (root, shoot, leaves) at varying growth stages viz; panicle initiation, $50 \%$ flowering and at harvest (Table 3 ). Application of customized fertilizer to pearl millet at panicle initiation enhanced iron concentration in shoots and leaves by 2.65 and $2.64 \%$, respectively, over control. Likewise, at $50 \%$ flowering stage, iron concentration increased by $4.70,2.21$ and $2.19 \%$, respectively, by root, shoot and leaves over control. Similarly, at the harvest stage also, customized fertilized improved iron concentration in root and shoot by 6.96 and $2.99 \%$, respectively, over control or no fertilizer treatment. Improvement in iron content by the crop might ascribe to enhanced immobilization of iron due to the addition of customized fertilizer supplying N, P, K and Zn. Fageria
(2001) find out that sufficient P-inputs in the soil enhance Fe immobilization. Similarly, Bolle-Jones (1955) studied potato fertilization in pot sand culture and found that added $\mathrm{K}$ reduced mild Fe deficiency symptoms thereby increasing Fe content in plant roots and other parts.

It is revealed from the data presented in Table 3 that varying pearl millet hybrids tested under the experimentation had a substantial influence on iron concentration in different plant parts viz; root, shoot and leaves of pearl millet. Pearl millet hybrid 'RHB 173' fetched markedly higher Fe concentration in shoots $\left(60.72 \mathrm{mg} \mathrm{kg}^{-1}\right)$ and leaves $\left(56.13 \mathrm{mg} \mathrm{kg}^{-1}\right)$ at panicle initiation, in shoots $\left(57.87 \mathrm{mg} \mathrm{kg}^{-1}\right)$ and leaves $(53.27 \mathrm{mg} \mathrm{kg}$ $\left.{ }^{1}\right)$ at $50 \%$ flowering and in shoots $\left(67.63 \mathrm{mg} \mathrm{kg}^{-1}\right)$ and leaves (45.92 $\mathrm{mg} \mathrm{kg}^{-1}$ ) at harvest stage. Albeit, 'HHB 67 Improved' recorded statistically higher iron concentration in roots at panicle initiation (38.77 $\mathrm{mg} \mathrm{kg}^{-1}$ ), 50\% flowering (38.06 mg $\mathrm{kg}^{-1}$ ) and at harvest stage (33.627 $\left.\mathrm{mg} \mathrm{kg}^{-1}\right)$. Variations in Fe concentrations among pearl millet hybrids might be due to large variations in morphological characters between crop species. In a research paper White et al. (2013) discussed root ideotypes for improving the acquisition of essential mineral elements and identified root growth vigor as globally important traits affecting the uptake of most essential nutrients. Bruck et al. (2003) and Palta and Watt (2009) have

\begin{tabular}{|c|c|c|c|c|c|c|c|c|c|}
\hline \multirow[t]{3}{*}{ Treatments } & \multicolumn{9}{|c|}{ Iron concentration $\left(\mathrm{mg} \mathrm{kg}^{-1}\right)$} \\
\hline & \multicolumn{3}{|c|}{ Panicle initiation } & \multicolumn{3}{|c|}{$50 \%$ flowering } & \multicolumn{3}{|c|}{ At harvest } \\
\hline & Root & Shoot & Leaf & Root & Shoot & Leaf & Root & Shoot & Leaf \\
\hline \multicolumn{10}{|l|}{ Fertilizers } \\
\hline Control & 34.96 & 57.38 & 53.73 & 33.53 & 54.64 & 50.99 & 28.45 & 64.08 & 44.01 \\
\hline Straight fertilizer & 35.58 & 58.09 & 54.10 & 34.53 & 55.31 & 51.32 & 29.48 & 65.01 & 43.94 \\
\hline Customized fertilizer & 35.68 & 58.90 & 55.15 & 35.20 & 55.85 & 52.11 & 30.43 & 66.00 & 44.18 \\
\hline SEm \pm & 0.43 & 0.05 & 0.05 & 0.05 & 0.06 & 0.05 & 0.04 & 0.07 & 0.14 \\
\hline$C D(p=0.05)$ & NS & 0.14 & 0.13 & 0.15 & 0.18 & 0.13 & 0.13 & 0.21 & NS \\
\hline \multicolumn{10}{|l|}{ Hybrids } \\
\hline MPMH 21 & 32.80 & 56.61 & 54.42 & 32.29 & 53.76 & 51.57 & 25.57 & 63.52 & 44.24 \\
\hline MPMH 17 & 34.38 & 57.91 & 53.16 & 33.23 & 55.06 & 50.31 & 26.59 & 64.82 & 42.81 \\
\hline RHB 177 & 36.62 & 58.55 & 54.18 & 35.32 & 55.70 & 51.33 & 29.35 & 65.46 & 44.24 \\
\hline RHB 173 & 35.03 & 60.72 & 56.13 & 35.93 & 57.87 & 53.27 & 31.81 & 67.63 & 45.92 \\
\hline HHB 67 Improved & 38.77 & 60.51 & 54.01 & 38.06 & 57.66 & 51.15 & 33.62 & 67.42 & 43.55 \\
\hline НHВ 197 & 38.34 & 57.95 & 53.38 & 33.04 & 55.09 & 50.53 & 28.47 & 64.86 & 42.95 \\
\hline HHB 272 & 31.93 & 54.60 & 55.02 & 33.07 & 51.75 & 52.17 & 30.75 & 61.51 & 44.58 \\
\hline SEm \pm & 0.65 & 0.08 & 0.07 & 0.08 & 0.10 & 0.07 & 0.07 & 0.11 & 0.21 \\
\hline$C D(p=0.05)$ & 1.83 & 0.22 & 0.20 & 0.23 & 0.27 & 0.20 & 0.19 & 0.31 & 0.58 \\
\hline \multicolumn{10}{|l|}{ Interaction } \\
\hline SEm \pm & 1.13 & 0.13 & 0.12 & 0.14 & 0.17 & 0.12 & 0.12 & 0.19 & 0.36 \\
\hline $\mathrm{CD}(p=0.05)$ & NS & 0.37 & 0.34 & 0.40 & 0.47 & 0.35 & NS & 0.54 & NS \\
\hline
\end{tabular}


also shown a positive relationship between vigorous shoot and root growth, coupled with an efficient uptake of soil nutrients. Thus, it is relevant to assess the variability of morphological traits viz; root, shoot and leaves and the associated uptake of nutrients in existing cultivars to be used for a low input production system.

\subsection{Nutritional enrichment of pearl millet grain and straw}

To mitigate the multi-nutrient malnutrition or hidden hunger, enrichment of grain for human health and straw for animals health through the novel approaches of Agronomic biofortification advocating customized fertilizer, is crucial and important. Application of customized fertilizer to pearl millet significantly enriched its grain and straw in terms of micronutrients ( $\mathrm{Zn}, \mathrm{Fe}, \mathrm{Mn}$ and $\mathrm{Cu}$ ) over control (Table 4). Substantially higher Zn (56.42 $\left.\mathrm{mg} \mathrm{kg}^{-1}\right)$, Fe (39.50 $\left.\mathrm{mg} \mathrm{kg}^{-1}\right) \mathrm{Mn}$ (15.13 $\mathrm{mg} \mathrm{kg}^{-1}$ ) and $\mathrm{Cu}\left(18.31 \mathrm{mg} \mathrm{kg}^{-1}\right)$ in grain were noticed due to the application of customized fertilizer. Likewise, the addition of pearl millet with customized fertilizer also had a marked influence on the concentration of $\mathrm{Zn}(30.03 \mathrm{mg}$ $\left.\mathrm{kg}^{-1}\right)$, Fe (69.07 $\left.\mathrm{mg} \mathrm{kg}^{-1}\right), \mathrm{Mn}\left(39.93 \mathrm{mg} \mathrm{kg}^{-1}\right)$ and $\mathrm{Cu}(24.90$ $\mathrm{mg} \mathrm{kg}^{-1}$ ) improvement in straw, an important source of fodder for milch animals in the arid region of India. Balanced macronutrient concentrations along with micronutrient zinc in the soil supplied through customized fertilizer were related to a higher ratio of root length to shoot dry matter, indicating that vigorous roots enable plants to absorb higher amounts of macro-and micronutrients from soil, and thereby supply higher micronutrient concentration to the straw and grain. The advantages of compound NPK fertilizers containing Zn had also been reported by Cakmak (2008) and Rietra et al. (2017). Positive interactions among applied soil nutrients add nutritional concentrations in plants (Graham and Rengel, 1993; Robson and Pitman, 1983)

Marked variation in micronutrient concentrations viz; $\mathrm{Zn}$, $\mathrm{Fe}, \mathrm{Mn}$ and $\mathrm{Cu}$ in pearl millet grain and straw have been recorded under varying pearl millet hybrids. A large variability for micronutrient content in germplasm and breeding lines has been indicated, suggesting the feasibility of genetic enhancement for micronutrients in pearl millet (Yadav and Rai, 2013; Yadav et al., 2021). The pearl millet hybrid 'HHB 67 Improved' recorded substantially higher $\mathrm{Zn}(61.97 \mathrm{mg}$ $\left.\mathrm{kg}^{-1}\right)$, Fe (43.98 $\left.\mathrm{mg} \mathrm{kg}^{-1}\right)$ and $\mathrm{Mn}\left(15.46 \mathrm{mg} \mathrm{kg}^{-1}\right)$ in grain and $\mathrm{Cu}$ (25.09 $\mathrm{mg} \mathrm{kg}^{-1}$ ) in straw. However, 'HHB 173' noticed a significantly higher $\mathrm{Cu}\left(19.60 \mathrm{mg} \mathrm{kg}^{-1}\right)$ concentration in grain. Albeit, in straw, significant improvement of $\mathrm{Zn}\left(31.36 \mathrm{mg} \mathrm{kg}^{-1}\right)$, Fe (68.97 $\left.\mathrm{mg} \mathrm{kg}^{-1}\right), \mathrm{Mn}\left(41.70 \mathrm{mg} \mathrm{kg}^{-1}\right)$ and $\mathrm{Cu}$ (25.09 $\mathrm{mg} \mathrm{kg}^{-1}$ ) was fetched by 'HHB 197', 'MPMH 17', 'MPMH 21' and 'HHB 67 Improved' pearl millet hybrids, respectively.

\begin{tabular}{|c|c|c|c|c|c|c|c|c|}
\hline \multirow[t]{2}{*}{ Treatments } & \multicolumn{4}{|c|}{ Nutrient concentration in grain $\left(\mathrm{mg} \mathrm{kg}^{-1}\right)$} & \multicolumn{4}{|c|}{ Nutrient concentration in straw $\left(\mathrm{mg} \mathrm{kg}^{-1}\right)$} \\
\hline & $\mathrm{Zn}$ & $\mathrm{Fe}$ & $\mathrm{Mn}$ & $\mathrm{Cu}$ & $\mathrm{Zn}$ & $\mathrm{Fe}$ & $\mathrm{Mn}$ & $\mathrm{Cu}$ \\
\hline \multicolumn{9}{|l|}{ Fertilizers } \\
\hline Control & 53.69 & 36.68 & 12.02 & 16.14 & 27.49 & 68.31 & 39.24 & 22.16 \\
\hline Straight fertilizer & 55.83 & 39.00 & 14.44 & 17.87 & 29.53 & 68.80 & 39.25 & 22.12 \\
\hline Customized fertilizer & 56.42 & 39.50 & 15.13 & 18.31 & 30.03 & 69.07 & 39.93 & 24.90 \\
\hline SEm \pm & 0.09 & 0.06 & 0.05 & 0.08 & 0.06 & 0.06 & 0.08 & 0.06 \\
\hline $\mathrm{CD}(p=0.05)$ & 0.26 & 0.18 & 0.14 & 0.24 & 0.18 & 0.18 & 0.24 & 0.18 \\
\hline \multicolumn{9}{|l|}{ Hybrids } \\
\hline MPMH 21 & 55.29 & 37.86 & 13.18 & 18.92 & 28.33 & 68.65 & 41.70 & 24.08 \\
\hline MPMH 17 & 61.25 & 39.59 & 13.42 & 16.35 & 29.31 & 68.97 & 41.19 & 23.31 \\
\hline RHB 177 & 55.96 & 37.50 & 13.39 & 18.64 & 28.52 & 68.65 & 40.55 & 23.51 \\
\hline RHB 173 & 53.88 & 37.78 & 14.47 & 19.60 & 28.44 & 68.63 & 41.15 & 22.79 \\
\hline HHB 67 Improved & 61.97 & 43.98 & 15.46 & 15.36 & 28.81 & 68.93 & 37.50 & 25.09 \\
\hline НHВ 197 & 48.89 & 33.52 & 13.10 & 18.54 & 31.36 & 68.64 & 40.11 & 22.51 \\
\hline HHB 272 & 49.93 & 38.52 & 14.03 & 14.67 & 28.35 & 68.62 & 34.12 & 20.13 \\
\hline SEm \pm & 0.14 & 0.10 & 0.07 & 0.13 & 0.10 & 0.10 & 0.13 & 0.10 \\
\hline $\operatorname{CD}(p=0.05)$ & 0.39 & 0.28 & 0.21 & 0.36 & 0.28 & 0.28 & 0.36 & 0.27 \\
\hline \multicolumn{9}{|l|}{ Interaction } \\
\hline SEm \pm & 0.24 & 0.17 & 0.13 & 0.22 & 0.17 & 0.17 & 0.22 & 0.17 \\
\hline $\operatorname{CD}(p=0.05)$ & NS & 0.48 & 0.36 & NS & NS & NS & 0.62 & 0.47 \\
\hline
\end{tabular}




\subsection{Nutrient acquisition and zinc use indices}

Application of customized fertilizer to pearl millet improved substantially uptake of $\mathrm{Zn}, \mathrm{Fe}, \mathrm{Mn}$ and $\mathrm{Cu}$ by grain and straw both (Figure 1 to 4). Application of customized fertilizer enhanced uptake of $\mathrm{Zn}, \mathrm{Fe}, \mathrm{Mn}$ and $\mathrm{Cu}$ by grain which was significantly higher by $12.3,12.4,16.4$ and $14.0 \%$, respectively. Likewise, customized fertilizer also substantially improved uptake of $\mathrm{Zn}, \mathrm{Fe}, \mathrm{Mn}$ and $\mathrm{Cu}$ by straw to the tune of 8.3, 5.5, 8.4 and $19.2 \%$ higher, respectively over straight fertilizers. The increment in micronutrient uptake reveal synergism with macronutrients. The addition of $\mathrm{Zn}$ and primary nutrients $(\mathrm{N}$, $P$ and $K$ ) resulted in a higher yield of pearl millet and thereby enhanced uptake of micronutrients (Rietra et al., 2017).

Significant differences in uptake of micronutrients viz; Zn, $\mathrm{Fe}, \mathrm{Mn}$ and $\mathrm{Cu}$ of pearl millet grain and straw have also been recorded due to varying hybrids undertaken in the

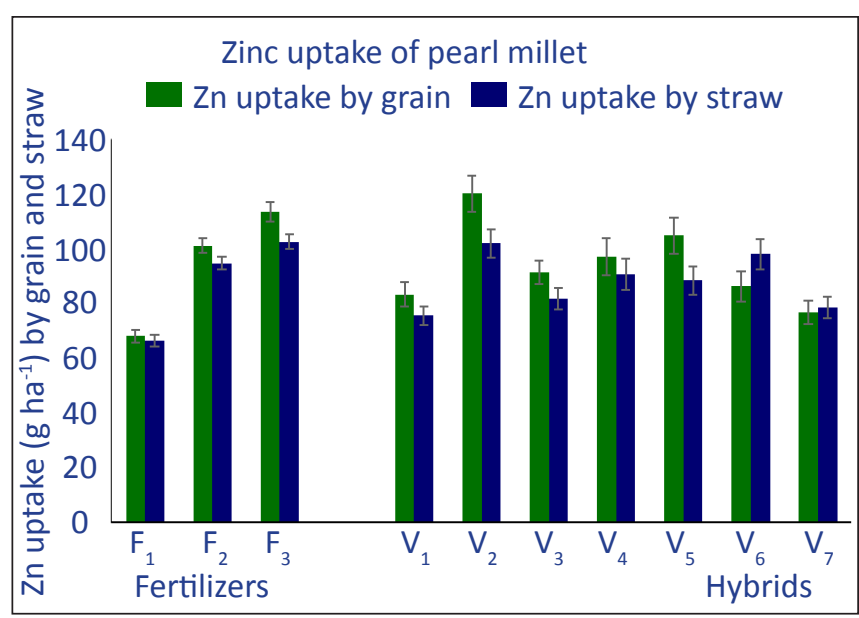

Figure 1: Effect of fertilizers and hybrids on zinc uptake (g $\left.\mathrm{ha}^{-1}\right)$ of pearl millet grain and straw. Bar show standard error of mean with LSD value at $p=0.05$ to determine the significance differences among the treatment mean

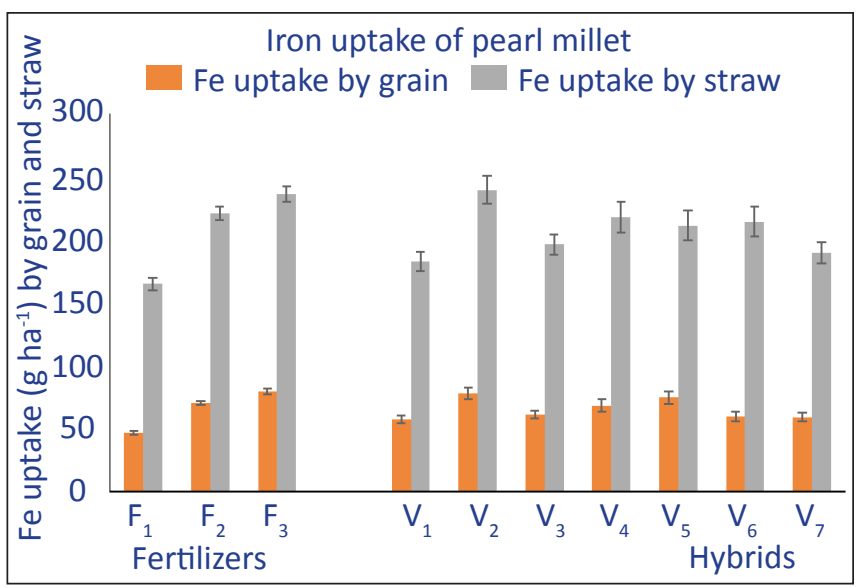

Figure 2: Effect of fertilizers and hybrids on iron uptake ( $\mathrm{g}$ ha$\left.{ }^{1}\right)$ of pearl millet grain and straw. Bar show standard error of mean with LSD value at $p=0.05$ to determine the significance differences among the treatment mean

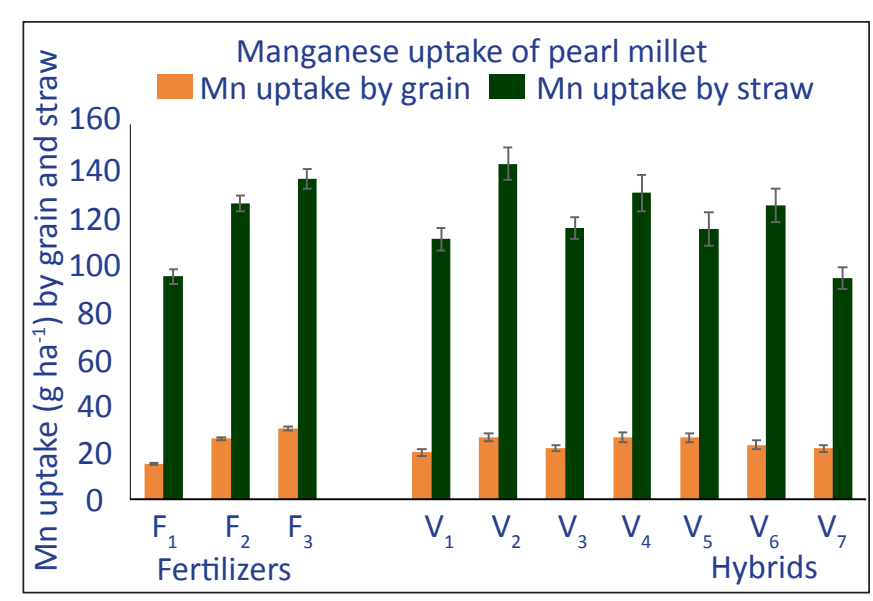

Figure 3: Effect of fertilizers and hybrids on manganese uptake ( $\mathrm{g} \mathrm{ha}^{-1}$ ) of pearl millet grain and straw. Bar show standard error of mean with LSD value at $p=0.05$ to determine the significance differences among the treatment mean

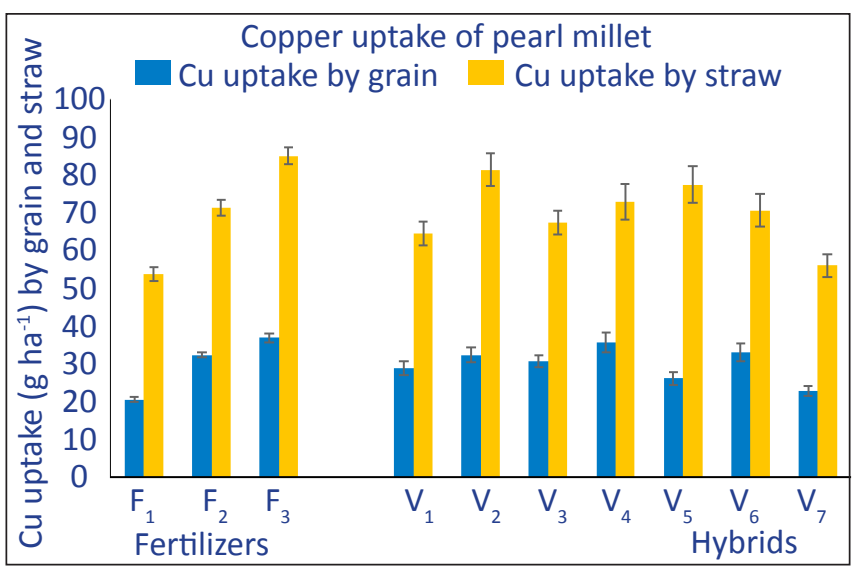

Figure 4: Effect of fertilizers and hybrids on copper uptake (g $\mathrm{ha}^{-1}$ ) of pearl millet grain and straw. Bar show standard error of mean with LSD value at $p=0.05$ to determine the significance differences among the treatment mean

experimentation (Figure 1 to 4). Among hybrids, 'MPMH 17' fetched highest acquisition of $\mathrm{Zn}\left(120.20 \mathrm{mg} \mathrm{kg}^{-1}\right)$, Fe $(77.86$ $\mathrm{mg} \mathrm{kg}^{-1}$ ), Mn (26.62 $\mathrm{mg} \mathrm{kg}^{-1}$ ) and 'RHB 173' of Cu (35.54 $\mathrm{mg} \mathrm{kg}^{-1}$ ) by grain which were markedly higher over rest of the hybrids. Similarly by straw, 'MPMH 17' fetched highest acquisition of Zn (96.04 $\left.\mathrm{mg} \mathrm{kg}^{-1}\right)$, Fe (222.53 $\left.\mathrm{mg} \mathrm{kg}^{-1}\right), \mathrm{Mn}\left(143.05 \mathrm{mg} \mathrm{kg}^{-1}\right.$ ) and $\mathrm{Cu}\left(81.25 \mathrm{mg} \mathrm{kg}^{-1}\right)$ which were noticeably higher over rest of the hybrids. Enhanced content and supply favoured increased micronutrients accumulation in the entire plant. Additionalyy, efficient genotypes have high capacity to absorb the nutrients from root zone and store relatively little nutrients (Graham and Rengel, 1993; Fageria, 2013; Hafeez et al., 2013).

In addition to nutrient acquisition, zinc use indices in terms of agronomic zinc use efficiency and zinc recovery efficiency (Table 5) influenced substantially due to application of customized fertilizers and hybrids. Application of customized fertilizer recorded significantly higher agronomic zinc use efficiency (149.3 kg grain $\mathrm{kg}^{-1} \mathrm{Zn}$ applied) and zinc recovery 


\begin{tabular}{|c|c|c|}
\hline Treatments & $\begin{array}{c}\text { Agronomic } \mathrm{Zn} \text { use } \\
\text { efficiency (kg grain } \mathrm{kg}^{-1} \\
\mathrm{Zn} \text { applied) }\end{array}$ & $\begin{array}{c}\text { Recovery } \\
\text { efficiency } \\
(\%)\end{array}$ \\
\hline \multicolumn{3}{|l|}{ Fertilizers } \\
\hline Control & - & - \\
\hline Straight fertilizer & 109.6 & 1.23 \\
\hline Customized fertilizer & 149.3 & 1.64 \\
\hline SEm \pm & 7.3 & 0.08 \\
\hline $\mathrm{CD}(p=0.05)$ & 20.6 & 0.22 \\
\hline \multicolumn{3}{|l|}{ Hybrids } \\
\hline MPMH 21 & 66.4 & 0.72 \\
\hline MPMH 17 & 100.0 & 1.16 \\
\hline RHB 177 & 58.7 & 0.63 \\
\hline RHB 173 & 106.1 & 1.16 \\
\hline HHB 67 Improved & 90.5 & 1.08 \\
\hline HHB 197 & 101.8 & 1.08 \\
\hline HНB 272 & 80.6 & 0.85 \\
\hline SEm \pm & 11.2 & 0.12 \\
\hline$C D(p=0.05)$ & 31.5 & 0.34 \\
\hline \multicolumn{3}{|l|}{ Interaction } \\
\hline SEm \pm & 19.4 & 0.21 \\
\hline$C D(p=0.05)$ & NS & NS \\
\hline
\end{tabular}

efficiency (1.64\%). On the other hand, among pearl millet hybrids, 'RHB 173' highest agronomic zinc use efficiency (106.1 $\mathrm{kg}$ grain $\mathrm{kg}^{-1} \mathrm{Zn}$ applied) and zinc recovery efficiency (1.16\%).

\subsection{Yield}

Data pertaining to grain and straw yield are presented in Table 6. Applying customized fertilizers to pearl millet gave significantly more yield (grain and straw yield) over no fertilizer. The addition of customized fertilizer recorded significantly higher grain $\left(2,010 \mathrm{~kg} \mathrm{ha}^{-1}\right)$ and straw $(3,417 \mathrm{~kg}$ $\mathrm{ha}^{-1}$ ) yield, which was higher by 59.14 and $41.67 \%$ respectively, over control. Achieving higher yield due to customized fertilizer ascribed to the balanced supply of the nutrients to the plants as per the demand and slow release matrix (Kumar and Singh, 2017; Singh et al., 2016a; Singh et al., 2017; Singh et al., 2020).

Substantial variations in grain and straw yield of pearl millet have also been recorded due to different hybrids undertaken in the experimentation. Among pearl millet hybrids, 'MPMH 17 ' out yielded (1,958 kg ha-1) followed by 'RHB 173' $(1,795$ $\left.\mathrm{kg} \mathrm{ha}^{-1}\right)$. In terms of straw yield, 'MPMH 17' recorded 3,466 kg straw ha-1 followed by 'RHB 173' $\left(3,170 \mathrm{~kg} \mathrm{ha}^{-1}\right)$, which was significantly superior over the rest of the hybrids. The differences in dry matter production and nutrient use
Table 6: Yield of pearl millet as influenced by fertilizers and hybrids (pooled data)

\begin{tabular}{lcc}
\hline Treatments & $\begin{array}{c}\text { Grain yield } \\
\left(\mathrm{kg} \mathrm{ha}^{-1}\right)\end{array}$ & $\begin{array}{c}\text { Straw yield } \\
\left(\mathrm{kg} \mathrm{ha}^{-1}\right)\end{array}$ \\
\hline Fertilizers & 1,263 & 2,412 \\
Control & 1,811 & 3,208 \\
Straight fertilizer & 2,010 & 3,417 \\
Customized fertilizer & 30 & 54 \\
SEm \pm & 86 & 153 \\
CD ( $p=0.05)$ & & \\
Hybrids & 1,502 & 2,661 \\
\hline MPMH 21 & 1,958 & 3,466 \\
MPMH 17 & 1,628 & 2,858 \\
RHB 177 & 1,795 & 3,170 \\
RHB 173 & 1,687 & 3,057 \\
HHB 67 Improved & 1,760 & 3,117 \\
HHB 197 & 1,531 & 2,757 \\
HHB 272 & 47 & 83 \\
SEm \pm & 131 & 234 \\
CD ( $p=0.05)$ & & \\
Interaction & 81 & 144 \\
SEm \pm & NS & NS \\
CD ( $p=0.05)$ & & \\
\hline
\end{tabular}

acquisition efficiencies between the hybrids of pearl millet might be attributed to the effect of the genetic makeup of the hybrids. These findings are closely correlated by Arshewar et al. (2018), Lagat et al. (2018) and Bijarnia et al. (2020).

\section{Conclusion}

Application of customized fertilizer (6:6:2:1) to pearl millet gave substantially higher grain yield $\left(2010 \mathrm{~kg} \mathrm{ha}^{-1}\right)$ and straw yield ( $3417 \mathrm{~kg} \mathrm{ha}^{-1}$ ). Micronutrient fortification ( $\mathrm{Zn}, \mathrm{Fe}, \mathrm{Mn}$ and $\mathrm{Cu}$ ) of grain and straw has been achieved with the application of customized fertilizer. Moreover, pearl millet hybrid 'MPMH 17 ' recorded significantly higher grain $\left(1,958 \mathrm{~kg} \mathrm{ha}^{-1}\right)$ and straw $\left(3,466 \mathrm{~kg} \mathrm{ha}^{-1}\right)$. Among hybrids, 'HHB 67 Improved' fetched the greatest concentration of $\mathrm{Zn}, \mathrm{Fe}$ and $\mathrm{Mn}$ in the grain.

\section{Further Research}

The slow release matrix of the developed customized fertilizer grade $(6: 6: 2: 1)$ should be tested under different soil types for all the individual elements viz; N, P, K and Zn.

\section{Acknowledgement}

The authors duly acknowledge the support received from the ICAR-All India Coordinated Research Project on Pearl Millet, Agricultural Research Station, Mandor, Jodhpur (Agriculture 
University, Jodhpur). Our sincere thanks are also due to the College of Agriculture, Agriculture University, Jodhpur for providing facilities for accomplishing the research work.

\section{References}

Alejandro, S., Holler, S., Meier, B., Peiter, E., 2020. Manganese in plants: from acquisition to subcellular allocation. Frontiers in Plant Science 11, 1-23. DOI: https://doi.org/10.3389/fpls.2020.00300

Anonymous, 2020. Estimates of area, production and yield of kharif cereals 2019-20. directorate of economics and statistics, department of agriculture cooperation and farmers welfare, Government of India. Available at: https://eands.dacnet.nic.in/APY_96_To_06.htm. Accessed on $11^{\text {th }}$ June, 2021.

Arshewar, S.P., Karanjikar, P.N., Dambaleand, A.S., Kawde, M.B., 2018. Effect of nitrogen and zinc levels on growth, yield and economics of pearl millet (Pennisetum glaucum L.). International Journal of Bio-resource and Stress Management 9(6), 729-732. DOI: https://doi. org/10.23910/IJBSM/2018.9.6.3C0549.

Beuerlein, J.E., Oplinger, E.S., Reicosky, D., 1992. The mineral content of soft winter wheat as influenced by nitrogen fertilization and management. Communications in Soil Science and Plant Analysis 23, 455-467.

Bijarnia, A.L., Singh, U., Sutaliya, R., 2020. Influence of integrated nutrient management on fodder pearl millet in transitional plain of Luni Basin. International Journal of Economic Plants 7(4), 193-196. DOI: https://doi. org/10.23910/2/2020.0391.

Bolle-Jones, E.W., 1955. The interactions of iron and potassium in the potato plant. Plant and Soil 6, 129-173.

Bouis, H.E.,Welch, R.M., 2010. Biofortification-a sustainable agricultural strategy for reducing micronutrient malnutrition in the global south. Crop Science 50, 20-32.

Bruck, H., Sattelmacher, B., Payne, W.A., 2003. Varietal differences in shoot and rooting parameters of pearl millet on sandy soils in Niger. Plant and Soil 251, 175185. DOI: https://doi.org/10.1023/A:1022932815486.

Cakmak, I., 2008. Zinc deficiency in wheat in Turkey. In: Alloway, B.J. (Eds.), Micronutrient deficiencies in global crop production. Springer, Dordrecht. Online ISBN 978-1-4020-6860-7. DOI: https://doi.org/10.1007/9781-4020-6860-7_7.

Cakmak, I., Kutman, U.B., 2017. Agronomic biofortification of cereals with zinc: a review. European Journal of Soil Science 69, 172-180. DOI: https://doi.org/10.1111/ ejss.12437

Dev, P., Singh, U., 2020. Optimization of zinc in mungbean [Vigna radiata (L.) Wilczek] varieties. M.Sc. Thesis, Department of Agronomy, College of Agriculture, Agriculture University, Jodhpur, Rajasthan.

Fageria, N.K., 2013. Mineral nutrition of rice. Boca Raton, FL: CRC Press. DOI: https://doi.org/10.1201/b15392.
Fageria, V.D., 2001. Nutrient interactions in crop plants. Journal of Plant Nutrition 24(8), 1269-1290.

Fisher, R.A., 1950. Statistical methods for research workers. Oliver and Boyd. Edinburg, London (UK).

Fisher, R.A., Yates, F., 1963. Statistical tables. Oliver and Boyd, Edinburgh, Tweeddate Court, London (U.K).

Frossard, E., Bucher, M., Machler, F., Mozafar, A., Hurrell, R., 2000. Potential for increasing the content and bioavailability of $\mathrm{Fe}, \mathrm{Zn}$ and $\mathrm{Ca}$ in plants for human nutrition. Journal of the Science of Food and Agriculture 80(7), 861-879.

Graham, R.D., Rengel, Z., 1993. Genotypic variation in zinc uptake and utilization by plants. In: Robson, A.D. (Eds.), Zinc in soils and plants. Developments in plant and Soil Sciences, 55, Springer, Dordrecht. DOI: https://doi. org/10.1007/978-94-011-0878-2_8.

Hafeez, B., Khanif, Y.M., Saleem, M., 2013. Role of zinc in plant nutrition-a review. American Journal of Experimental Agriculture 3(2), 374-391.

Jakhar, S.R., Singh, M., Balai, C.M., 2006. Effect of farmyard manure, phosphorus and zinc levels on growth, yield, quality and economics of Pearl millet (Pennisetum glaucum). Indian Journal of Agricultural Sciences 76(1), 58-61.

Kumar, L., Singh, U., 2017. Enhancing nutrient use efficiency through differential formulations of fertilizers having slow release matrix. In: Singh, U., Praharaj, C.S., Kumar, N., Deo, M.M., Kumar, L. (Eds.), Enhancing nutrient use efficiency through next generation fertilizers in field crops, 43-52. Training Manual (10/2017), ICAR-Indian Institute of Pulses Research, Kanpur, Uttar Pradesh- 208 024, India.

Karmakar, M., Sarkar, N.C., Shivay, Y.S., 2021. Agronomic biofortification of zinc in lentil. International Journal of Bio-resource and Stress Management 12(2), 095-107. DOI: https://doi.org/10.23910/1.2021.2150a.

Lagat, N., Kimurto, P., Kiplagat, O., Towett, B.K., Jeptanui, L., Gatongi, I., Njogu, N., Ojulong, H., Manyasa, E., 2018. Evaluation of genotypexenvironment interaction and stability of grain yield and related yield components in pearl millet (Pennisetum glaucum (L.) R. Br.). Journal of Experimental Agriculture International 21(1), 1-18. DOI: https://doi.org/10.9734/JEAl/2018/24311.

Marschner, H., 1995. Mineral nutrition of higher plants $\left(2^{\text {nd }}\right.$ Edn.). London, UK Academic Press.

Morrissey, J., Guerinot, M.L., 2009. Iron uptake and transport in plants: the good, the bad, and the ionome. Chemical reviews 109(10), 4553-4567. DOI: https://doi.org/10.1021/cr900112r.

Palta, J.A., Watt, M., 2009. Crop roots systems form and function: improving the capture of water and nutrients with vigorous root systems. In: Sadras, V., Calderini, D. (Eds.), Crop physiology: application for genetic improvement and agronomy. San Diego, CA: Academic Press, 309-325. 
Rengel, Z., Batten, G.D., Crowley, D.E., 1999. Agronomic approaches for improving the micronutrient density in edible portions of field crops. Field Crops Research 60, 27-40.

Rietra, R.P.J.J., Heinen, M., Dimkpa, C.O., Bindraban, P.S., 2017. Effects of nutrient antagonism and synergism on yield and fertilizer use efficiency. Communications in Soil Science and Plant Analysis 48(16), 1895-1920. DOI: https://doi.org/10.1080/00103624.2017.1407429.

Robson, A.D., Pitman M.G., 1983. Interactions between nutrients in higher plants. In: Lauchli, A., Bieleski, R.L. (Eds.), Inorganic plant nutrition. Encyclopedia of Plant Physiology (New Series) 15. Springer, Berlin, Heidelberg. DOI: https://doi.org/10.1007/978-3-642-68885-0_6

Sadeghzadeh, B., 2013. A review of zinc nutrition and plant breeding. Journal of Soil Science and Plant Nutrition 13(4), 905-927.

Samreen, T., Humaira., Shah, H.U., Ullah, S., Javid, M., 2017. Zinc effect on growth rate, chlorophyll, protein and mineral contents of hydroponically grown mungbeans plant (Vigna radiata). Arabian Journal of Chemistry 10(2), S1802-S1807. DOI: https://doi.org/10.1016/j. arabjc.2013.07.005

Shahzad, Z., Rouached, H., Rakha, A., 2014. Combating mineral malnutrition through iron and zinc biofortification of cereals. Comprehensive Reviews in Food Science and Food Safety 13, 329-346. DOI: https://doi. org/10.1111/1541-4337.12063

Singh, U., Kumar, N., Praharaj, C.S., Singh, S.S., Kumar, L., 2015. Ferti-fortification: an easy approach for nutritional enrichment of chickpea. The Ecoscan 9(3\&4), 731-736.

Singh, U., Praharaj, C.S., Singh, S.S., Bohra, A., Shivay, Y.S., 2015a. Biofortification of pulses: strategies and challenges. International Journal of Economic Plants 2(3), 140-144.

Singh, U., Praharaj, C.S., Chaturvedi, S.K., Bohra, A., 2016. Biofortification: introduction, approaches, limitations and challenges. In: Singh, U., Praharaj, C.S., Chaturvedi, S.K., Bohra, A. (Eds.), biofortification of food crops Springer (India) Pvt. Ltd., New Delhi), 3-18. DOI: https:// doi.org/10.1007/978-81-322-2716-8_1
Singh, U., Kumar, L., Praharaj, C.S., Singh, S.S., Srivastava, G.K., 2016a. Customized fertilizers enhances NUE and PFP. Pulses Newsletter IIPR 27(2), 2.

Singh, U., Praharaj, C.S., 2017. Chemical analysis of soil and plant samples. Practical Manual (13/2017), ICAR-Indian Institute of Pulses Research, Kanpur, Uttar Pradesh- 208 024, India, 1-58.

Singh, U., Praharaj, C.S., Kumar, N., Deo, M.M., Kumar, L., 2017. Enhancing nutrient use efficiency through next generation fertilizers in field crops. Training Manual (10/2017), ICAR-Indian Institute of Pulses Research, Kanpur, Uttar Pradesh- 208 024, India, 1-229.

Singh, U., Praharaj, C.S., Kumar, L., Kumar, R., 2020. Customized fertilizers: an intervention to enhance nutrient use efficiency and productivity of pulses. Pp. 246. In: Dixit et al., 2020 (Eds.), Abstracts, International Conference (ICPulse2020) on Pulses as the Climate Smart Crops: Challenges and Opportunities, ICARIndian Institute of Pulses Research, Kanpur organized by ISPRD, ICAR-IIPR, Kanpur at Bhopal during February 10-12, 2020.

White, P.J., Broadley, M.R., 2009. Biofortification of crops with seven mineral elements often lacking in human diets iron, zinc, copper, calcium, magnesium, selenium and iodine. New Phytologist 182, 49-84.

White, P.J., George, T.S., Dupuy, L.X., Karley, A.J., Valentine, T.A., Wiesel, L., Wishart, J., 2013. Root traits for infertile soils. Frontiers in Plant Science 4, 193. DOI: https://doi. org/10.3389/fpls.2013.00193.

Yadav, O.P., Rai, K.N., 2013. Genetic improvement of pearl millet in India. Agricultural Research 2(4), 275-292. DOI: https://doi.org/10.1007/s40003-013-0089-z.

Yadav, O.P., Gupta, S.K., Govindaraj, M., Sharma, R., Varshney, R.K., Srivastava, R.K., Rathore, A., Mahala, R.S., 2021. Genetic gains in pearl millet in India: Insights into historic breeding strategies and future perspective. Frontiers in Plant Science 12, 1-15. DOI: https://doi.org/10.3389/ fpls.2021.645038. 